University of Rhode Island

DigitalCommons@URI

The Rhode Island Current Conditions Index

Economics

\title{
$5-2011$
}

\section{Rhode Island Current Conditions Index - May 2011}

Leonard Lardaro

University of Rhode Island, lardaro@uri.edu

Follow this and additional works at: https://digitalcommons.uri.edu/ricci

Part of the Econometrics Commons

Terms of Use

All rights reserved under copyright.

\section{Recommended Citation}

Lardaro, Leonard, "Rhode Island Current Conditions Index - May 2011" (2011). The Rhode Island Current Conditions Index. Paper 34.

https://digitalcommons.uri.edu/ricci/34

This Article is brought to you for free and open access by the Economics at DigitalCommons@URI. It has been accepted for inclusion in The Rhode Island Current Conditions Index by an authorized administrator of DigitalCommons@URI.For more information, please contact digitalcommons-group@uri.edu. 


\section{CURRENT \\ CONDITIONS NDEX}

VOL XVII I NUMBER 6 MAY 2011

\section{LEONARD LARDARO, URI}

\section{Available Online: http:/ / members.cox.net/ lardaro/ current.htm}

The second quarter hasn't been all that kind to Rhode Island. For May, the Current Conditions Index remained at 58, its third consecutive month at that value, as only seven of twelve indicators improved relative to their values a year ago. Clearly, Rhode Island's rate of economic growth has slowed and may well be plateauing. This becomes apparent by comparing $\mathrm{CCl}$ values for each month of this year with their corresponding values last year. For March, April, and May, the three months with $\mathrm{CCl}$ values of 58, 2011 values have fallen below their 2010 levels. And, unlike what we have seen in the last two months, where more than half of the CCl's indicators had very difficult "comps" to beat from a year ago, this was true for only four indicators in May.

In addition to this, the trends in several indicators appear to have changed in ways that will make it more difficult for our rate of

\begin{tabular}{|l|r|r|}
\hline \multicolumn{3}{|c|}{ CCI Indicators - \% Change } \\
\hline Government Employment & -4.8 & \\
\hline US Consumer Sentiment & 0.3 & Y \\
\hline Single-Unit Permits & -23.9 & \\
\hline Retail Sales & 0.9 & Y \\
\hline Employment Services J obs & -4.9 & \\
\hline Priv. Serv-Prod Employment & 2.0 & Y \\
\hline Total Manufacturing Hours & 2.7 & Y \\
\hline Manufacturing Wage & 6.7 & Y \\
\hline Labor Force & -1.2 & \\
\hline Benefit Exhaustions & 5.3 & \\
\hline New Claims & -20.7 & Y \\
\hline Unemployment Rate (change) & -0.8 & Y \\
\hline \multicolumn{2}{|c|}{ Y = I mproved Value } \\
\hline
\end{tabular}

growth to increase from its current level. The indicators I am referring to are the Labor Force, which has now declined or failed to improve for the last four months, and the number of Employment Service Jobs, a leading labor market indicator that includes "temps," which has now fallen for the past three months. Finally, there have been several very pleasant surprises, most notably strength in our state's manufacturing sector, leading the way throughout this recovery. But it appears that the momentum provided by that sector, especially Total Manufacturing Hours, may be fading. It is not clear at this point which indicators will be able to replace our manufacturing-based momentum.

The improving indicators this month were led by manufacturing strength, which has now been true for some time. Total Manufacturing Hours increased by 2.7 percent, its twelfth improvement in the last thirteen months, while the Manufacturing Wage rose by an amazing 6.7 percent, in part reflecting labor skill shortages. Retail Sales rose by 0.9 percent in May (my estimate), in spite of having risen by over 5 percent one year ago. Along with this, US Consumer Sentiment rose by only 0.3 percent versus last May, but this month's improvement reverses two months of declines. New Claims, a leading labor market indicator that reflects layoffs, fell by 20.7 percent this month, its fifth consecutive improvement. Private ServiceProducing Employment rose by 2 percent in May, its most rapid rate of growth in a long time. Unfortunately the benefits of this were somewhat offset by public sector employment weakness. Government Employment fell sharply, declining just under 5 percent in May, as budget cuts continued to exert negative pressure on our economy. Our state's Unemployment Rate dropped sharply again, from 11.7 percent one year ago to 10.9 percent in May. That, however, was not necessarily good news, as our Labor Force failed to improve for the fourth consecutive month, reflecting what is becoming a disturbing trend of unemployed persons dropping out of the Labor Force, which helps to lower our jobless rate.

Single-Unit Permits, which reflects new home construction, continued its roller coaster performance, declining by 23.9 percent in May, its fifth consecutive double-digit decline, and ninth decrease in the last twelve months. And, as if that's not bad enough, the actual number of permits for May for the entire state was only 51. Employment Service J obs, a leading indicator that was once our "star" performer in this recovery, fell by 4.9 percent in May, its third consecutive decline. Finally, Benefit Exhaustions, which reflects long-term unemployment, rose by 5.3 percent in May, although it had a very difficult comp to beat from a year ago $(-23.4 \%)$.

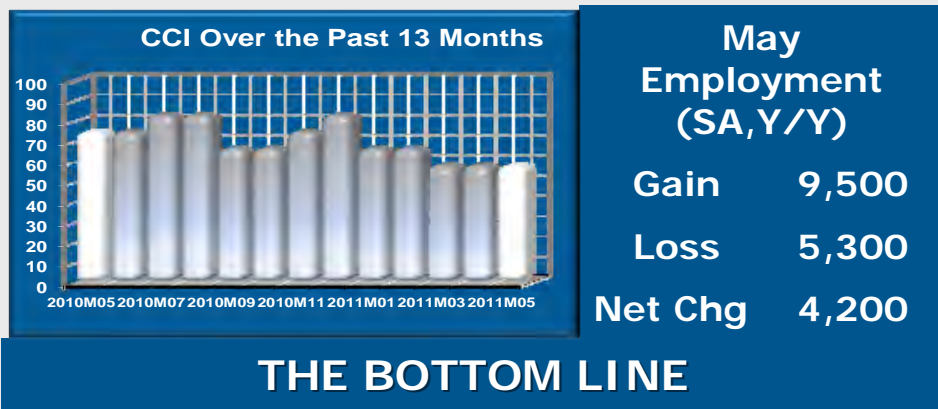

In spite of all the trends currently taking place here, it is important to keep in mind that Rhode Island is in an economic recovery. May marked the sixteenth month of this recovery, so we do have substantial cyclical momentum and a "margin for error." Unfortunately, Rhode Island is also plagued by a host of structural negatives that sap a great deal of its cyclical momentum. What is at issue here should be how rapidly our state's recovery proceeds from here, not when or whether this recovery might end.

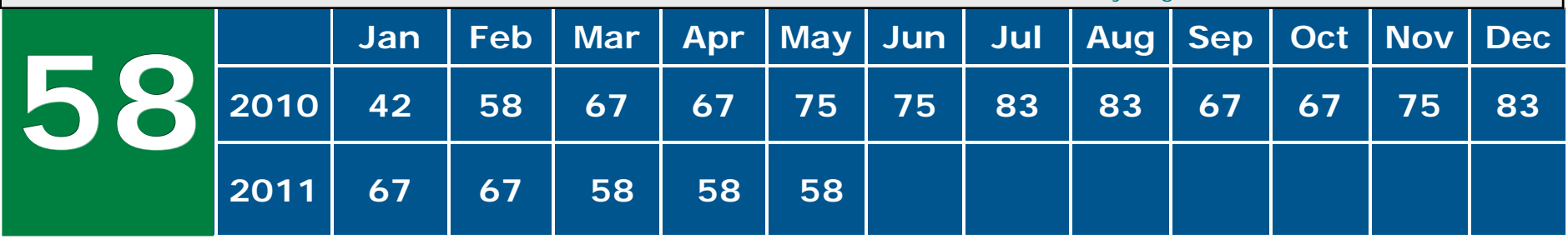

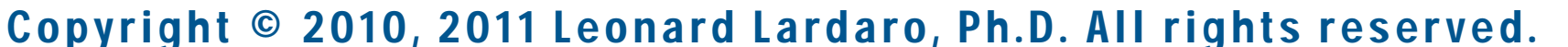

